\title{
Avaliação da resistência de tricostrongilos na bovinocultura leiteira a anti-helmíntico
}

Greiciele Hoffmann Pessoa, Eduarda Cesari, Alessom Serafini, Eduardo Fabiani, Everton Cannini, Angela Faccin, Daniela

Oliveira, Franciele Oliveira

Instituto de Desenvolvimento Educacional do Alto Uruguai (IDEAU), Caxias do Sul, RS, Brasil

*Autor correspondente

e-mail: greici.pessoa@hotmail.com

Resumo

Na pecuária leiteira, as helmintoses assumem papel de grande importância para a sanidade dos animais de produção e muitas das vezes passam despercebidas à atenção do criador e até mesmo de profissionais e técnicos, em função da pouca evidência dos sintomas clínicos, principalmente no início da infecção. Este trabalho teve como objetivo avaliar a presença de tricostrongilídeos em bovinos de produção de leite, cultivá-los em coprocultura e analisar sua resistência in vitro a determinados anti-helmínticos utilizados na região. Foram coletadas 20 amostras de fezes em três diferentes municípios, as quais foram levadas até o laboratório para sua avaliação através de flutuação e coprocultura, onde em seguida foram expostas à diferentes princípios ativos para avaliar sua resistência e, posteriormente, apresentar as possíveis causas e tratamento a fim de não gerar prejuízos à propriedade. Dentre as propriedades analisadas, um único bovino apresentou o parasita. Nas amostras que continham Doramectina em todas as concentrações foi possível observar a presença de larvas; já nas amostras que continham Ivermectina, somente na concentração de 100\% não foram encontradas larvas. 0 T. axei é a espécie que parasita o abomaso dos ruminantes; sua prevalência é baixa e apresenta pouca importância epidemiológica. 0 T. colubriformis é de maior prevalência e localiza-se no intestino delgado dos ruminantes, provocando sérias lesões e podendo causar atrofia das microvilosidades intestinais. 0 animal identificado no presente trabalho como portador do parasita apresentou como sinais clínicos diarreia e perda de peso. A diarreia ocorre pelo quadro de enterite que se estabelece no animal parasitado. Geralmente, a suspeita da resistência anti-helmíntica ocorre quando se obtém uma baixa resposta ao uso do fármaco. 0 processo de seleção de indivíduos resistentes ocorre de forma gradativa e, caso não haja diagnóstico precoce, a resistência será observada somente quando estes sinais clínicos forem notados no animal parasitado. Observando as amostras e diagnosticando que 
houve presença e resistência da Triconstrongilose aos anti-helmínticos mais utilizados na região, conclui-se que deve-se ter uma preocupação maior com as resistências, pois acometem os animais causando sérios prejuízos às propriedades. A propriedade onde se encontrou a resistência por parte do parasita deve ser tratada e todas devem adotar um cronograma para aplicação de anti-helmínticos. 